bioRxiv preprint doi: https://doi.org/10.1101/2020.06.24 168518; this version posted June 24, 2020. The copyright holder for this preprint (which was not certified by peer review) is the author/funder, who has granted bioRxiv a license to display the preprint in perpetuity. It is made available under aCC-BY-ND 4.0 International license.

\title{
Enhanced anti-amyloid effect of combined leptin and pioglitazone in APP/PS1
}

\section{transgenic mice}

Yao Liu ${ }^{\text {a*}}$, Kelsey A. Hanson ${ }^{c}$, Graeme McCormack ${ }^{\mathrm{a}}$, Justin Dittmann, James C. Vickers ${ }^{\mathrm{a}}$, Carmen M. FernandezMartos $^{* b^{\dagger}}$ and Anna E. King ${ }^{\text {a }}$

${ }^{a}$ Wicking Dementia Research and Education Centre, College of Health and Medicine, University of Tasmania, Private Bag 143, Hobart, Tasmania 7001, Australia.

${ }^{b}$ Research Unit of the National Hospital of Paraplegics (UDI-HNP), Finca La Peraleda s/n, Toledo 45007, Spain.

${ }^{c}$ University of Manchester, Division of Neuroscience \& Experimental Psychology 46 Grafton Street Manchester M13 9NT, $U K$.

"These authors are both corresponding authors

†These authors are both last authors

Running title: Combinational therapy for AD

*Corresponding author: Dr Carmen M. Fernandez-Martos (submitting author)

Primary Email: cmfernandezm@sescam.jccm.es

Secondary Email: Carmen.fernandezmartos@utas.edu.au

Phone: +34 925247789

Fax: +34 925247745

*Co-corresponding author: Dr Yao Liu

Email: Yao.Liu@utas.edu.au

Phone: +61 408232935

Fax: +61362264833 
bioRxiv preprint doi: https://doi org/10.1101/2020.06 24 168518; this version posted June 24, 2020. The copyright holder for this preprint (which was not certified by peer review) is the author/funder, who has granted bioRxiv a license to display the preprint in perpetuity. It is made available under aCC-BY-ND 4.0 International license.

\section{ABSTRACT}

Background: Alzheimer's disease (AD) has challenged single-target therapeutic strategies, raising the possibility that combined therapies may offer a more effective treatment strategy.

Objective: There is substantial evidence for the efficacy of leptin (L) (neuroprotective hormone) and pioglitazone (P) (anti-inflammatory agent) as monotherapies in $\mathrm{AD}$. We have previouly shown that combination treatment of $\mathrm{L}+\mathrm{P}$ in APP/PS1 mice at the onset of pathology significantly improved memory and reduced brain A $\beta$ levels relative to control mice. In this new study, we sought to replicate our previous findings in a new cohort of APP/PS1 mouse to further confirm whether the combined treatment of $\mathrm{L}+\mathrm{P}$ is superior to each treatment individually.

Methods: We have re-evaluated the effects of L+P co-treatment in APP/PS1 mice using thioflavin-S staining, MOA $\beta$ immunolabeling and enzyme-linked immunosorbent assay (ELISA) to examine effects on $A \beta$ levels and pathology, relative to animals that received $\mathrm{L}$ or $\mathrm{P}$ individually. To explore mechanism of regulation, we used Western blotting to examine the expression of the peroxisome-proliferator activated receptor $\gamma(\operatorname{PPAR} \gamma)$, due to its potential role in the regulation of the inflammatory response.

Results: We demonstrated that combining $\mathrm{L}$ and $\mathrm{P}$ significantly enhances the anti-A $\beta$ effect of $\mathrm{L}$ or $\mathrm{P}$ in the hippocampus of APP/PS1 mice. Western blot analysis indicated that $\mathrm{A} \beta$ reduction was accompanied by up-regulation of the PPAR $\gamma$ levels.

Conclusion: Our findings suggest that combining $\mathrm{L}$ and $\mathrm{P}$ significantly enhances the anti-A $\beta$ effect of $\mathrm{L}$ or $\mathrm{P}$ in the hippocampus of APP/PS1 mice, and may be a potential new effective strategy for AD therapy.

Keywords: Alzheimer's disease (AD); Leptin, Pioglitazone; APP/PS1 transgenic mouse; signaling pathways. 
bioRxiv preprint doi: https://doi org/10.1101/2020.06.24.168518; this version posted June 24,2020 . The copyright holder for this preprint (which was not certified by peer review) is the author/funder, who has granted bioRxiv a license to display the preprint in perpetuity. It is made available under aCC-BY-ND 4.0 International license.

\section{INTRODUCTION}

Alzheimer's disease (AD) accounts for approximately 60-70\% of dementia cases. AD is characterized by extracellular amyloid-beta $(\mathrm{A} \beta)$ deposits, intracellular neurofibrillary tangles [1] and clinical symptoms of cognitive impairment. As current evidence indicates that $\mathrm{A} \beta$ deposits begin to form in the brain long before the onset of AD symptoms [2-5], interventions specifically aimed at disaggregating existing $\mathrm{A} \beta$ plaques and reducing $\mathrm{A} \beta$ oligomers may constitute a useful approach to $\mathrm{AD}$ therapy. However, anti-A $\beta$ agents have not yielded expected outcomes clinically, which may be due to the incomplete removal of pre-existing $\mathrm{A} \beta$ aggregates. In addition, none of the developing anti-A $\beta$ singletarget drugs survived phase III clinical trials [6], which indicate that single-target drugs are limited in the treatment of AD. Thus, there is an urgent need to re-examine the validity of the A $\beta$-targeting approaches and to develop new effective strategies.

Pioglitazone (P), an agonist of nuclear peroxisome-proliferator activated receptor $\gamma(\mathrm{PPAR} \gamma)$, is a drug that is used to treat type-2 diabetes through modulation of metabolic pathways. Recent studies have shown that $\mathrm{P}$ might provide a protective effect on $\mathrm{AD}$ risk among individuals with type-2 diabetes [7], suggesting that drugs used to treat diabetes may also be efficacious in $\mathrm{AD}$. In this regard, $\mathrm{P}$ has anti-inflammatory properties [6; 8], improves spatial memory in $\mathrm{AD}$ mouse models and $\mathrm{AD}$ patients [9] and has demonstrated reduced $\mathrm{A} \beta$ plaques in experimental models [6; 10; 11], through mechanisms related to the amyloid degradation $[12 ; 13]$. The effect of $\mathrm{P}$ on reducing soluble $\mathrm{A} \beta$ species in models of AD may also be partly mediated by PPAR $\gamma[12]$.

A range of studies at both the clinical and pre-clinical level indicate that disrupted leptin (L) signalling pathways are linked to the pathophysiology of AD [14-18]. Furthermore, accumulating in vivo and in vitro studies have suggested that $\mathrm{L}$ has notable effects on reducing $\mathrm{A} \beta$ production $[19 ; 20]$ and enhancing neuroprotection [21-24]. In the brain, the binding of $\mathrm{L}$ to the neuronal receptor $\mathrm{Ob}-\mathrm{Rb}$ activates janus-tyrosine kinase 2 (JAK2), resulting in the activation of the phosphatidylinositol-3-kinase/Akt (PI3K/Akt), JAK/signal transducers and activators of transcription (JAK/STAT), and $5^{\prime}$ adenosine monophosphate-activated protein kinase/sirtuin (AMPK/SIRT) pathways, potentially reducing A $\beta$ production and increasing its clearance, and reducing tau phosphorylation [25].

We have previously reported that co-treatment of the anti-inflammatory $\mathrm{P}$, and the neuroprotective L, significantly reduced hippocampal $\mathrm{A} \beta$ levels (soluble $\mathrm{A} \beta$ and fibrillary $\mathrm{A} \beta$ plaque burden) in a transgenic (Tg) mouse model of $\mathrm{AD}$ expresses human presenilin 1 (PS1) with deltaE9 mutation and a chimeric mouse/human A $\beta$ precursor protein (APP) harboring the Swedish mutation (APPswe/PSEN1dE9) [21]. However, in our first study, the L and P drugs were not tested independently under the same experimental conditions. In addition, the failure of translation from animal studies has led to the scientific community increasing research on potential therapeutics in animals, including 
bioRxiv preprint doi: $\mathrm{https}$ ://doi.org/10.1101/2020.06.24 168518; this version posted June 24, 2020. The copyright holder for this preprint (which was not certified by peer review) is the author/funder, who has granted bioRxiv a license to display the preprint in perpetuity. It is made available under aCC-BY-ND 4.0 International license.

performing replication studies [26-28], prior to progressing to clinical studies. Therefore, in the current study, we sought to replicate our previous study in a new cohort of APP/PS1 mice using thioflavin-S staining, MOA $\beta$ immunolabeling and enzyme-linked immunosorbent assay (ELISA) to examine effects on A $\beta$ levels and pathology, relative to animals that received $\mathrm{L}$ or $\mathrm{P}$ individually. In addition, we examined the protein expression of PPAR $\gamma$, by using Western blotting, due to the potential role for PPAR $\gamma$ expressed in astrocytes and microglial cells in the regulation of the inflammatory response [8]. 
bioRxiv preprint doi: https://doi.org/10.1101/2020.06 24 168518; this version posted June 24 2020. The copyright holder for this preprint (which was not certified by peer review) is the author/funder, who has granted bioRxiv a license to display the preprint in perpetuity. It is made available under aCC-BY-ND 4.0 International license.

\section{METHODS}

\subsection{Animals}

Male APP/PS1 (APPswe/PSEN1dE9) Tg mice and age-matched wildtype (WT) littermates maintained on a C57BL/6 background [26] were used in this study. The maintenance and use of mice and all experimental procedures were approved by the Animal Ethics Committee of the University of Tasmania (A0013939 \& A0016308), in accordance with the Australian Guidelines for the Care and Use of Animals for Scientific Purposes. All analyses were conducted by personnel blinded to the animal genotype.

\subsection{Experimental Design}

Male APP/PS1 mice and WT littermate controls, were treated with drugs at 28 weeks of age, a time when plaques are beginning to develop [27]. Animals were administered daily treatments of L (delivered IN) and/or P (delivered IP) or vehicle control for two weeks as previously described with modifications [21]. Treatment groups are summarized in Table 1. Mice were sacrificed at 40 weeks of age. Brain tissue was used for the analysis of A $\beta$ plaque load and Western Blot analysis. (Fig. 1). Numbers of mice used in each analysis are summarized in Table 2.

\subsection{Drug administration}

Each genotype of mice was divided into four subgroups $(n=5-9$ Tg mice/ subgroup and $n=10$ WT mice/ subgroup) according to the treatments. Therefore, there were eight groups in total (Table 1). Pioglitazone (Takeda Pharmaceuticals) solution was prepared in 1:3 dimethyl sulfoxide (DMSO, Cayman Chemical): phosphate buffered saline (PBS, pH 7.2), and leptin solution was prepared in $0.125 \%$ (2.3mM) of N-tetradecyl-b-D-maltoside (TDM) (Sigma-Aldrich) reconstituted in PBS ( $\mathrm{pH} 7.2)$ at a concentration of $1 \mathrm{mg} / \mathrm{mL}$.

Mice received once daily IP injection of $150-200 \mu \mathrm{L}$ of $20 \mathrm{mg} / \mathrm{kg}$ of pioglitazone solution or vehicle control $(1: 3$ DMSO: PBS; pH 7.2). Following injection, IN treatments were given under light $3 \%$ isoflurane anesthesia. A $30 \mu \mathrm{L}$ pipette bearing a $20 \mu \mathrm{L}$ long gel loading tip was used to introduce $20 \mu \mathrm{L}$ of $0.03 \mathrm{mg} / \mathrm{kg}$ leptin (Sigma-Aldrich) solution or vehicle control $(0.125 \%$ TDM/PBS; $\mathrm{pH} 7.2)$ into the nasal cavity via only one of the external nares. Nares were alternated each day during the 2 -week treatment starting with the left side. We selected IN administration for $\mathrm{L}$ delivery as it is a common technique in laboratory rodents, enabling administration of small drug volumes relative to other routes. Additionally, the nasal mucosa are richly supplied with blood vessels, potentially resulting in rapid substance absorption and subsequent systemic effects, avoiding the hepatic first-pass effect seen with oral delivery [28]. Both administration routes are commonly used as non-invasive drug administration techniques, which promote a minimal discomfort [28-30].

\subsection{Tissue preparation}


bioRxiv preprint doi: https://doi org/10.1101/2020.06.24.168518; this version posted June 24,2020 . The copyright holder for this preprint (which was not certified by peer review) is the author/funder, who has granted bioRxiv a license to display the preprint in perpetuity. It is made available under aCC-BY-ND 4.0 International license.

Animals were terminally anesthetized with sodium pentobarbitone $(140 \mathrm{mg} / \mathrm{kg})$ and transcardiacally perfused with 0.01M PBS (pH 7.4). Brains were immediately dissected, and right hemispheres were post-fixed overnight in $4 \%$ paraformaldehyde (PFA in $0.01 \mathrm{M}$ PBS), and then transferred to $18 \%$ and then $30 \%$ sucrose solutions overnight [31]. Serial coronal cryosections ( $40 \mu \mathrm{m}$ thick) from right hemispheres were cut on a cryostat (Leica CM 1850). Tissue samples of neocortex (CTX) and hippocampus (HP) were dissected from left hemispheres and snap frozen in liquid nitrogen followed by storage at $-80^{\circ} \mathrm{C}$ for later analysis.

\subsection{A $\beta$ plaque load}

To determine $\mathrm{A} \beta$ plaque load in the CTX and HP, quantitation of fibrillar A $\beta$ (Thioflavin-S staining) or total A $\beta$ (MOA $\beta$-2 immunolabeling) deposition was performed for four groups of APP/PS1 mice (Table 2). Serial coronal cryosections (40 $\mu \mathrm{m}$ thick) from right hemispheres were stained with thioflavin-S as previously described [32], to visualize fibrillar and dense-core $A \beta$ plaques, or immunolabelled for $A \beta$ plaques using the mouse anti-MOA $\beta-2$ (1:1000; Novus Biologicals) antibody following antigen retrieval with formic acid (90\%, 8 minutes) treatment [33], which specifically detects A $\beta$ but not APP [34; 35]. Primary antibody binding was visualized using species specific fluorescent secondary antibodies conjugated to Alexa Fluor goat anti-mouse 488 (1:1000; Molecular Probes). Sections were mounted using fluorescent mounting medium (DAKO).

Slides containing brain sections were scanned via a VS120 slide scanner and whole brain sections imaged on a fluorescence microscope (Olympus). Images were analyzed with ImageJ software to quantify numbers and pixel areas of $\mathrm{A} \beta$ plaques. The whole CTX from the mid-line to the rhinal fissure from one hemisphere of the brain as well as the whole hippocampal formation was quantitated for each brain section. Segmentation of images was performed using the ImageSURF plugin which automatically segments images as plaques or background pixels by random forest classification [36]. A $\beta$ plaque load (defined as percentage area thioflavin-S positive or MOA $\beta-2$ labelling of the total area analyzed) was quantitated [33; 37]. In all cases, the specificity of immunoreactivity was confirmed by processing sections lacking primary antibody. All analyses were conducted by personnel blinded to animal genotype and treatment.

\subsection{Protein preparation}

The left sides of the CTX and HP from the four subgroups of WT and Tg mice (Table 2), respectively, were homogenized in RIPA buffer (Sigma) containing a protease inhibitor cocktail (Roche) and phosphatase inhibitors (AG Scientific) as previously described [38]. The samples were sonicated for 5 minutes and then centrifuged for 5 minutes at 13,000 RPM. The resulting supernatant was removed and stored at $-20^{\circ} \mathrm{C}$ for Western blots or ELISA analysis. Protein concentration was determined with a bicinchoninic acid (BCA) assay kit (Invitrogen) according to the 
bioRxiv preprint doi: https://doi.org/10.1101/2020.06 24.168518; this version posted June 24, 2020. The copyright holder for this preprint (which was not certified by peer review) is the author/funder, who has granted bioRxiv a license to display the preprint in perpetuity. It is made available under aCC-BY-ND 4.0 International license.

manufacturer's instructions. Bovine serum albumin (BSA) was used as a standard.

\subsection{Western blotting}

Western blotting was performed as previously described [38] with modifications. Protein samples from the HP of all eight groups of mice (Table 2) were used. Proteins $(15 \mu \mathrm{g})$ were separated on 4-20\% Bolt Bis-Tris Plus gels (Invitrogen), as described previously $[15,25]$. The gel was subsequently transferred onto a polyvinylidene fluoride (PVDF) membrane (Bio-Rad) and blocked with 5\% (w/v) non-fat milk tris-buffered saline (TBS) with $0.1 \%$ Tween20 (Bio-Rad) for 1 hour at room temperature. The membrane was then incubated with rabbit anti- PPAR $\gamma(1: 1000$, Cell Signaling) primary antibody at $4{ }^{\circ} \mathrm{C}$ overnight. Subsequently, a corresponding anti-rabbit horseradish peroxidase (HRP)-conjugated secondary antibody (1:5000; DAKO) was applied. Binding was visualized with enhanced chemiluminescence solution using Luminata Forte Western horseradish peroxidase (HRP) substrate (Millipore). Band intensity was measured as the sum optical density by using ImageJ software (version1.4; NIH) and normalized to control labelling of glyceraldehyde 3-phosphate dehydrogenase (GAPDH; 1:5000, Millipore).

\subsection{A $\beta_{1-42}$ ELISA}

The quantitation of soluble human $A \beta_{1-42}$ in hippocampus extracts was determined with a sandwich antibody ELISA kit (Invitrogen), according to the manufacturer's instructions. Duplicate HP samples from four groups of APP/PS1 mice (Table 2) were used for ELISA analyses. Optical densities were read at 450nm on a microplate reader (Tecan), and concentrations of $A \beta_{1-42}$ were determined by comparison to the standard curve using a 4-parameter algorithm. Soluble $A \beta_{1-42}$ levels were normalized to total protein levels, and HP homogenates were expressed as picograms of $\mathrm{A} \beta_{1-42}$ content per milligram (pg/mg) of total protein [21].

\subsection{Statistical analysis}

Statistical analysis was performed using GraphPad Prism (version 6.0; GraphPad Software, La Jolla, CA, USA). All values are expressed as the mean \pm standard error of the mean (SEM). Two-way analysis of variance (ANOVA) was used followed by Dunnett's post hoc test, to compare all groups with control group (WT VH group or APP/PS1 VH group), while the non-parametric Student $t$ test was used for the comparisons between APP/PS1 L and APP/PS1 L+P groups, and between APP/PS1 P and APP/PS1 L+P groups. 
bioRxiv preprint doi: https://doi org/10.1101/2020.06.24.168518; this version posted June 24 2020. The copyright holder for this preprint (which was not certified by peer review) is the author/funder, who has granted bioRxiv a license to display the preprint in perpetuity. It is made available under aCC-BY-ND 4.0 International license.

\section{RESULTS}

\subsection{Combined treatment of $\mathrm{L}+\mathrm{P}$ reduced Thioflavin-S-positive Aß plaques in the hippocampus of APP/PS1} mice to a greater degree that either single treatment alone

To assess the $A \beta$ deposition in the brain, we analyzed fibrillar $A \beta$ plaque load by thioflavin-S staining (Fig. 2) and by immunostaining of total human oligomeric, and fibrillar forms of $\mathrm{A} \beta_{1-42}$ with the MOA $\beta-2$ antibody (Fig. 3), in the HP and CTX of APP/PS1 L, APP/PS1 P, APP/PS1 L+P and APP/PS1 VH mice. Dunnett's post hoc test demonstrated that $\mathrm{L}+\mathrm{P}$ treatment significantly $(\mathrm{p}<0.05)$ reduced thioflavin-S-positive plaque deposition in the HP of APP/PS1 mice compared with APP/PS1 VH control group (Fig. 2A). In addition, APP/PS1 L mice as well as APP/PS1 P mice were not significantly different compared with APP/PS1 VH control group (Fig. 2A). These results indicated that the combination of $\mathrm{L}+\mathrm{P}$ reduce thioflavin-S-positive A $\beta$ plaque burden in the HP of APP/PS1 mice. However, there was no effect of any of the treatments on thioflavin-S-positive A $\beta$ load in the CTX of APP/PS1 mice relative to APP/PS1 VH mice (Fig. 2B).

Furthermore, there were no significant alterations to MOA $\beta-2-$ labelled A $\beta$ load in either HP (Fig. 3A) or CTX (Fig. 3B) of APP/PS1 L, APP/PS1 P, APP/PS1 L+P mice relative to APP/PS1 VH mice.

\subsection{Enhanced effect of combined treatment of $L+P$ on levels of soluble $A \beta_{1-42}$ in the hippocampus of APP/PS1} mice

We further performed sandwich ELISA using the extracts from the HP of four groups of APP/PS1 mice to determine the level of soluble $A \beta_{1-42}$. Compared with APP/PS1 VH mice, the amounts of $A \beta_{1-42}$ were significantly decreased in the mice administered with $\mathrm{L}$ alone $(\mathrm{p}<0.05)$ or $\mathrm{L}+\mathrm{P}(\mathrm{p}<0.01)$ (Fig. 4). In addition, the level of soluble $\mathrm{A} \beta_{1-42}$ decreased by $63.04 \%$ in the L-treated group and by $36.22 \%$ in the P-treated group, respectively. In the L+P group, $\mathrm{A} \beta_{1-42}$ levels dropped by $80.54 \%$ (Fig. 4).

\section{3. Effects of the treatments on the molecular regulation of PPAR $\gamma$ levels in the hippocampus of APP/PS1} mice

We next investigated if mechanism underlying the reduction of $A \beta$ load in the brain of APP/PS1 mice could be partially mediated by the molecular regulation of PPAR $\gamma$ levels, which play a master role in the regulation of the neuroinflammatory processes in AD (Fig 5). Indeed, previous research has demonstrated that $\mathrm{P}$ reduces A $\beta$ deposition in association with Akt/GSK3 $\beta$ activation by increasing the levels of insulin-degrading enzyme (IDE) and PPAR $\gamma$ expression [39]. For that reasons, in the current study, the downstream effect of treatment on PPAR $\gamma$ was investigated. Immunoblotting analysis showed PPAR $\gamma$ levels were significantly $(\mathrm{P}<0.05)$ increased in the HP of APP/PS1 VH mice relative to WT VH mice (Fig. 5A-B). Interestingly, PPAR $\gamma$ levels were significantly increased in WT mice following 
bioRxiv preprint doi: https://doi.org/10.1101/2020.06.24.168518; this version posted June 24, 2020. The copyright holder for this preprint (which was not certified by peer review) is the author/funder, who has granted bioRxiv a license to display the preprint in perpetuity. It is made available under aCC-BY-ND 4.0 International license.

$\mathrm{L}+\mathrm{P}$ treatment (Fig. 5B). There was also a significant $(\mathrm{p}<0.05)$ increase of PPAR $\gamma$ in the HP of APP/PS1 L mice, APP/PS1 P mice and APP/PS1 L+P mice, relative to APP/PS1 VH mice (Fig. 5B). Remarkably, combined treatment of $\mathrm{L}+\mathrm{P}$ resulted in a significant $(\mathrm{p}<0.05)$ increase of PPAR $\gamma$ in the HP of APP/PS1 mice, relative to single treatment of L or P (Fig. 5B). 
bioRxiv preprint doi: https://doi org/10.1101/2020.06.24.168518; this version posted June 24,2020 . The copyright holder for this preprint (which was not certified by peer review) is the author/funder, who has granted bioRxiv a license to display the preprint in perpetuity. It is made available under aCC-BY-ND 4.0 International license.

\section{DISCUSSION}

Numerous drugs have been proposed for AD, however there have been no effective treatments developed to date. The majority of therapeutic agents have been developed as monotherapies however, studies suggest that some combination therapies may have synergistic effects in $\mathrm{AD}$ (e.g. memantine and donepezil combination therapy [40]. Thus, there is a great need for studies using combination therapy in $\mathrm{AD}$, based on the available drugs. We have previouly shown that combination treatment of L+P in APP/PS1 mice at the onset of pathology significantly improved memory and reduced brain $\mathrm{A} \beta$ levels (soluble $\mathrm{A} \beta$ and $\mathrm{A} \beta$ plaque burden) relative to APP/PS1 VH mice [21]. Our present study confirmed these findings, and further show that $\mathrm{L}+\mathrm{P}$ effects on plaque load and soluble $\mathrm{A} \beta_{1-42}$ were greater than either $\mathrm{L}$ alone or $\mathrm{P}$ alone, and that combination treatment further reduced soluble $\mathrm{A} \beta_{1-42}$. Therefore, taken together both studies further confirm $\mathrm{L}+\mathrm{P}$ combination treatment might have additive or synergistic anti-A $\beta$ effects, suggesting that this combined anti-A $\beta$ therapy may be more effective than the monotherapy of $\mathrm{L}$ alone or $\mathrm{P}$ alone.

$\mathrm{A} \beta$ is currently a major target of $\mathrm{AD}$ therapy, as self-assembly of $\mathrm{A} \beta$ monomers into soluble oligomers and/or insoluble fibrils is linked to cognitive impairment of $\mathrm{AD}$ [41]. Therefore, many current therapeutic approaches are based on targeting the reduction of $\mathrm{A} \beta$ levels and preventing the production and aggregation of $\mathrm{A} \beta$ [42-45]. Failures of human clinical trials in anti-A $\beta$ monotherapies and a growing awareness of the complexity of AD have led to a focus on the potential of combination treatments as a new approach to reduce AD pathology. For example, co-administration of 4-(2-hydroxyethyl)-1-piperazinepropane-sulphonic acid (EPPS), an amyloid-clearing chemical, and donepezil, an acetylcholinesterase inhibitor, led to a rapid and consistent cognitive improvement in $\mathrm{AD}$ Tg mice [46].

A new direction for $\mathrm{AD}$ research is identifying drugs already used clinically to treat other diseases and to potentially employ them in combination [47]. Indeed, a minimum of six different agent classes (including anti-inflammatory agents, e.g. pioglitazone) are approved for clinical use, or are ready for phase III clinical trials as monotherapy in AD [48; 49]. These therapeutic agents have a potential to be used as combination therapy but, only a few clinical studies have been published that have investigated the effects of a combination therapy versus monotherapy on AD [48]. Our current study suggests the combination treatment of the neuroprotective hormone (L), and the anti-inflammatory and antidiabetic drug (P), may have additive or synergistic effects on reducing brain A $\beta$ levels through signalling pathways, highlighting the combined treatment of $\mathrm{L}$ and $\mathrm{P}$ as a promising treatment for $\mathrm{AD}$. $\mathrm{P}$ has been shown to be effective and well-tolerated in the treatment of patients with type-2 diabetes [50]. A phase II study of P in AD showed that $\mathrm{P}$ is safe and well-tolerated [51]. In addtion, L-replacement therapy is an effective and safe treatment for longterm improvement of glucose and lipid metabolism and complications in generalized lipodystrophy [52]. Therefore, it 
bioRxiv preprint doi: https://doi. org/10.1101/2020.06.24 168518; this version posted June 24, 2020. The copyright holder for this preprint (which was not certified by peer review) is the author/funder, who has granted bioRxiv a license to display the preprint in perpetuity. It is made available under aCC-BY-ND 4.0 International license.

is highly likely that combinatorial treatment of $\mathrm{L}+\mathrm{P}$ may be a safe and effective therapy. And $\mathrm{L}+\mathrm{P}$ treatment may be a successful translation from animal models to clinical trials for AD in the future.

In the current study, we examined a key downstream pathway of leptin and pioglitazone signalling, PPAR $\gamma$. Our finding that PPAR $\gamma$ was increased in the HP of APP/PS1 mice following $\mathrm{L}$ or $\mathrm{P}$ alone, or $\mathrm{L}+\mathrm{P}$ confirms reports demonstrating a significant increase in PPAR $\gamma$ protein levels in neurons incubated with P [53] and in spinal cord injury after L treatment [54]. PPAR $\gamma$ agonists, including P, have been shown to induce neuroprotective effects from A $\beta$ peptide neurotoxicity on hippocampal neurons [55]. In cultured cells, PPAR $\gamma$ overexpression diminishes A $\beta$ production [56]. Moreover, by inducing PPAR $\gamma$ expression and activation, L can reduce beta-secretase 1 (BACE1) expression [57]. These findings in the current study suggest that upregulation of PPAR $\gamma$ may be responsible for reduced $\mathrm{A} \beta$ load.

In summary, to our knowledge, our study is the first to demonstrate that combined treatment of $\mathrm{L}+\mathrm{P}$ reduces soluble $\mathrm{A} \beta$ and fibrillary $\mathrm{A} \beta$ plaque burden in the hippocampus of APP/PS1 mice by a possible synergistic or additive mechanism of the individual drugs. Our findings indicated that this combination of the neuroprotective hormone and the anti-inflammatory therapeutic strategy would result in a further $A \beta$ reduction than the single treatment of $L$ alone or $\mathrm{P}$ alone. Although combinatorial treatment of $\mathrm{L}+\mathrm{P}$ may be a safe and effective therapy, further pharmacoepidemiologic studies are still warranted before the clinical use of this combined treatment in AD.

Furthermore, we found that $\mathrm{L}+\mathrm{P}$ increased the protein expression of PPAR $\gamma$, which could potentially improve memory function via the transcriptional regulation of BDNF expression [58]. Indeed, it has been suggested that PPAR $\gamma$ agonists prevent the impairment of synaptic plasticity by increasing BDNF expression and dendrite spine density [59]. However, future studies will be necessary to determine whether combining L+P treatment also improves learning through regulation of brain $\mathrm{A} \beta$ levels in $\mathrm{AD}$. Our data indicate that this combination therapy may show promise in the clinic as a pathway to reducing $A \beta$ burden. 
bioRxiv preprint doi: https://doi org/10.1101/2020.06.24 168518; this version posted June 24, 2020. The copyright holder for this preprint (which was not certified by peer review) is the author/funder, who has granted bioRxiv a license to display the preprint in perpetuity. It is made available under aCC-BY-ND 4.0 International license.

\section{ACKNOWLEDGEMENTS}

The authors would like to gratefully acknowledge Jamuna Chhetri and Alexander Cronk for excellent technical support. The work was supported by the funding from the JO and JR Wicking Trust (Equity Trustees).

\section{AUTHOR CONTRIBUTIONS}

Conceptualization: Carmen M. Fernandez-Martos, James C. Vickers, and Anna E. King.

Data Analysis: Yao Liu, Kelsey A. Hanson and Carmen M. Fernandez-Martos.

Investigation: Yao Liu, Kelsey A. Hanson, Graeme McCormack, and Justin Dittmann.

Funding Acquisition: James C. Vickers and Anna E. King.

Methodology: Yao Liu, Carmen M. Fernandez-Martos, Anna E. King, and James C. Vickers.

Resources: James C. Vickers and Anna E. King.

Supervision: James C. Vickers, Carmen M. Fernandez-Martos and Anna E. King.

Writing-original draft: Yao Liu.

Writing-reviewed \&editing: Anna E. King, Carmen M. Fernandez-Martos, Kelsey A. Hanson, James C. Vickers.

\section{CONFLICT OF INTEREST}

The authors declare that they have no conflict of interest. Required Author Forms Disclosure forms provided by the authors are available with the online version of this article. 
bioRxiv preprint doi: https://doi org/10.1101/2020.06 24 168518; this version posted June 24, 2020. The copyright holder for this preprint (which was not certified by peer review) is the author/funder, who has granted bioRxiv a license to display the preprint in perpetuity. It is made available under aCC-BY-ND 4.0 International license.

\section{REFERENCES}

[1] Ballard C, Gauthier S, Corbett A, Brayne C, Aarsland D, Jones E. Alzheimer's disease. Lancet 377(9770): 101931.(2011).

[2] Braak H, Thal DR, Ghebremedhin E, Del Tredici K. Stages of the pathologic process in Alzheimer disease: age categories from 1 to 100 years. J Neuropathol Exp Neurol 70(11): 960-9.(2011).

[3] Medina-Franco JL, Martinez-Mayorga K, Meurice N. Balancing novelty with confined chemical space in modern drug discovery. Expert Opin Drug Discov 9(2): 151-65.(2014).

[4] Vickers JC, Mitew S, Woodhouse A, Fernandez-Martos CM, Kirkcaldie MT, Canty AJ, et al. Defining the earliest pathological changes of Alzheimer's disease. Curr Alzheimer Res 13(3): 281-7.(2016).

[5] Villemagne VL, Burnham S, Bourgeat P, Brown B, Ellis KA, Salvado O, et al. Amyloid beta deposition, neurodegeneration, and cognitive decline in sporadic Alzheimer's disease: a prospective cohort study. Lancet Neurol 12(4): 357-67.(2013).

[6] Nicolakakis N, Aboulkassim T, Ongali B, Lecrux C, Fernandes P, Rosa-Neto P, et al. Complete rescue of cerebrovascular function in aged Alzheimer's disease transgenic mice by antioxidants and pioglitazone, a peroxisome proliferator-activated receptor gamma agonist. J Neurosci 28(37): 9287-96.(2008).

[7] Tseng CH. Pioglitazone Reduces Dementia Risk in Patients with Type 2 Diabetes Mellitus: A Retrospective Cohort Analysis. J Clin Med 7(10)2018).

[8] Heneka MT, Sastre M, Dumitrescu-Ozimek L, Hanke A, Dewachter I, Kuiperi C, et al. Acute treatment with the PPARgamma agonist pioglitazone and ibuprofen reduces glial inflammation and Abeta1-42 levels in APPV717I transgenic mice. Brain 128(Pt 6): 1442-53.(2005).

[9] Sato T, Hanyu H, Hirao K, Kanetaka H, Sakurai H, Iwamoto T. Efficacy of PPAR-gamma agonist pioglitazone in mild Alzheimer disease. Neurobiol Aging 32(9): 1626-33.(2011).

[10] Searcy JL, Phelps JT, Pancani T, Kadish I, Popovic J, Anderson KL, et al. Long-term pioglitazone treatment improves learning and attenuates pathological markers in a mouse model of Alzheimer's disease. J Alzheimers Dis 30(4): 943-61.(2012).

[11] Papadopoulos P, Rosa-Neto P, Rochford J, Hamel E. Pioglitazone improves reversal learning and exerts mixed cerebrovascular effects in a mouse model of Alzheimer's disease with combined amyloid-beta and cerebrovascular pathology. PLoS One 8(7): e68612.(2013). 
bioRxiv preprint doi: https://doi org/10.1101/2020.06 24 168518; this version posted June 24, 2020. The copyright holder for this preprint (which was not certified by peer review) is the author/funder, who has granted bioRxiv a license to display the preprint in perpetuity. It is made available under aCC-BY-ND 4.0 International license.

[12] Mandrekar-Colucci S, Karlo JC, Landreth GE. Mechanisms underlying the rapid peroxisome proliferatoractivated receptor-gamma-mediated amyloid clearance and reversal of cognitive deficits in a murine model of Alzheimer's disease. J Neurosci 32(30): 10117-28.(2012).

[13] Camacho IE, Serneels L, Spittaels K, Merchiers P, Dominguez D, De Strooper B. Peroxisome-proliferatoractivated receptor gamma induces a clearance mechanism for the amyloid-beta peptide. J Neurosci 24(48): 1090817.(2004).

[14] Bonda DJ, Stone JG, Torres SL, Siedlak SL, Perry G, Kryscio R, et al. Dysregulation of leptin signaling in Alzheimer disease: evidence for neuronal leptin resistance. J Neurochem 128(1): 162-72.(2014).

[15] Lieb W, Beiser AS, Vasan RS, Tan ZS, Au R, Harris TB, et al. Association of plasma leptin levels with incident Alzheimer disease and MRI measures of brain aging. Jama 302(23): 2565-72.(2009).

[16] Power DA, Noel J, Collins R, O'Neill D. Circulating leptin levels and weight loss in Alzheimer's disease patients. Dement Geriatr Cogn Disord 12(2): 167-70.(2001).

[17] Rosenbaum M, Nicolson M, Hirsch J, Heymsfield SB, Gallagher D, Chu F, et al. Effects of gender, body composition, and menopause on plasma concentrations of leptin. J Clin Endocrinol Metab 81(9): 3424-7.(1996).

[18] Tezapsidis N, Johnston JM, Smith MA, Ashford JW, Casadesus G, Robakis NK, et al. Leptin: a novel therapeutic strategy for Alzheimer's disease. J Alzheimers Dis 16(4): 731-40.(2009).

[19] Weng Z, Signore AP, Gao Y, Wang S, Zhang F, Hastings T, et al. Leptin protects against 6-hydroxydopamineinduced dopaminergic cell death via mitogen-activated protein kinase signaling. J Biol Chem 282(47): 3447991.(2007).

[20] Zhang F, Wang S, Signore AP, Chen J. Neuroprotective effects of leptin against ischemic injury induced by oxygen-glucose deprivation and transient cerebral ischemia. Stroke 38(8): 2329-36.(2007).

[21] Fernandez-Martos CM. Combination treatment with leptin and pioglitazone in a mouse model of Alzheimer's disease. Alzheimer's \& Dementia: Translational Research \& Clinical Interventions 3: 92-106.(2017).

[22] Marwarha G, Dasari B, Prasanthi JR, Schommer J, Ghribi O. Leptin reduces the accumulation of Abeta and phosphorylated tau induced by 27-hydroxycholesterol in rabbit organotypic slices. J Alzheimers Dis 19(3): 1007-19.(

[23] Bahor Z, Liao J, Macleod MR, Bannach-Brown A, McCann SK, Wever KE, et al. Risk of bias reporting in the recent animal focal cerebral ischaemia literature. Clin Sci (Lond) 131(20): 2525-32.(2017).

[24] Begley CG, Ellis LM. Drug development: Raise standards for preclinical cancer research. Nature 483(7391): 531 3.(2012). 
bioRxiv preprint doi: https://doi org/101101/2020.06.24 168518; this version posted June 24,2020. The copyright holder for this preprint (which was not certified by peer review) is the author/funder, who has granted bioRxiv a license to display the preprint in perpetuity. It is made available under aCC-BY-ND 4.0 International license.

[25] Folch J, Patraca I, Martinez N, Pedros I, Petrov D, Ettcheto M, et al. The role of leptin in the sporadic form of Alzheimer's disease. Interactions with the adipokines amylin, ghrelin and the pituitary hormone prolactin. Life Sci 140: 19-28.(2015).

[26] Jankowsky JL, Fadale DJ, Anderson J, Xu GM, Gonzales V, Jenkins NA, et al. Mutant presenilins specifically elevate the levels of the 42 residue beta-amyloid peptide in vivo: evidence for augmentation of a 42 -specific gamma secretase. Hum Mol Genet 13(2): 159-70.(2004).

[27] Garcia-Alloza M, Robbins EM, Zhang-Nunes SX, Purcell SM, Betensky RA, Raju S, et al. Characterization of amyloid deposition in the APPswe/PS1dE9 mouse model of Alzheimer disease. Neurobiol Dis 24(3): 516-24.(2006).

[28] Turner CL, Eggleston GW, Lunos S, Johnson N, Wiedmann TS, Bowles WR. Sniffing out endodontic pain: use of an intranasal analgesic in a randomized clinical trial. J Endod 37(4): 439-44.(2011).

[29] Rosseels V, Naze F, De Craeye S, Francart A, Kalai M, Van Gucht S. A non-invasive intranasal inoculation technique using isoflurane anesthesia to infect the brain of mice with rabies virus. J Virol Methods 173(1): 12736.(2011).

[30] Wu S, Li K, Yan Y, Gran B, Han Y, Zhou F, et al. Intranasal Delivery of Neural Stem Cells: A CNS-specific, Non-invasive Cell-based Therapy for Experimental Autoimmune Encephalomyelitis. J Clin Cell Immunol 4(3)2013).

[31] Liu Y, Staal JA, Canty AJ, Kirkcaldie MT, King AE, Bibari O, et al. Cytoskeletal changes during development and aging in the cortex of neurofilament light protein knockout mice. J Comp Neurol 521(8): 1817-27.(2013).

[32] Mitew S, Kirkcaldie MT, Dickson TC, Vickers JC. Neurites containing the neurofilament-triplet proteins are selectively vulnerable to cytoskeletal pathology in Alzheimer's disease and transgenic mouse models. Front Neuroanat 7: 30.(2013).

[33] Collins JM, King AE, Woodhouse A, Kirkcaldie MT, Vickers JC. The effect of focal brain injury on betaamyloid plaque deposition, inflammation and synapses in the APP/PS1 mouse model of Alzheimer's disease. Exp Neurol 267: 219-29.(2015).

[34] Youmans KL, Tai LM, Kanekiyo T, Stine WB, Jr., Michon SC, Nwabuisi-Heath E, et al. Intraneuronal Abeta detection in 5xFAD mice by a new Abeta-specific antibody. Mol Neurodegener 7: 8.(2012).

[35] Youmans KL, Tai LM, Nwabuisi-Heath E, Jungbauer L, Kanekiyo T, Gan M, et al. APOE4-specific changes in Abeta accumulation in a new transgenic mouse model of Alzheimer disease. J Biol Chem 287(50): 41774-86.(2012).

[36] O'Mara AR, Collins JM, King AE, Vickers JC, Kirkcaldie MTK. Accurate and Unbiased Quantitation of Amyloid-beta Fluorescence Images Using ImageSURF. Curr Alzheimer Res 16(2): 102-08.(2019). 
bioRxiv preprint doi: https://doi org/101101/2020 06.24 168518; this version posted June 24, 2020. The copyright holder for this preprint (which was not certified by peer review) is the author/funder, who has granted bioRxiv a license to display the preprint in perpetuity. It is made available under aCC-BY-ND 4.0 International license.

[37] Atkinson RA, Fernandez-Martos CM, Atkin JD, Vickers JC, King AE. C9ORF72 expression and cellular localization over mouse development. Acta Neuropathol Commun 3(1): 59.(2015).

[38] Liu Y, Atkinson RA, Fernandez-Martos CM, Kirkcaldie MT, Cui H, Vickers JC, et al. Changes in TDP-43 expression in development, aging, and in the neurofilament light protein knockout mouse. Neurobiol Aging 36(2): 1151-9.(2015).

[39] Wang Q, Yuan J, Yu Z, Lin L, Jiang Y, Cao Z, et al. FGF21 Attenuates High-Fat Diet-Induced Cognitive Impairment via Metabolic Regulation and Anti-inflammation of Obese Mice. Mol Neurobiol 55(6): 4702-17.(2018).

[40] Owen RT. Memantine and donepezil: a fixed drug combination for the treatment of moderate to severe Alzheimer's dementia. Drugs Today (Barc) 52(4): 239-48.(2016).

[41] Karran E, Mercken M, De Strooper B. The amyloid cascade hypothesis for Alzheimer's disease: an appraisal for the development of therapeutics. Nat Rev Drug Discov 10(9): 698-712.(2011).

[42] Gervais F, Paquette J, Morissette C, Krzywkowski P, Yu M, Azzi M, et al. Targeting soluble Abeta peptide with Tramiprosate for the treatment of brain amyloidosis. Neurobiol Aging 28(4): 537-47.(2007).

[43] McLaurin J, Kierstead ME, Brown ME, Hawkes CA, Lambermon MH, Phinney AL, et al. Cyclohexanehexol inhibitors of Abeta aggregation prevent and reverse Alzheimer phenotype in a mouse model. Nat Med 12(7): 8018.(2006).

[44] Salomone S, Caraci F, Leggio GM, Fedotova J, Drago F. New pharmacological strategies for treatment of Alzheimer's disease: focus on disease modifying drugs. Br J Clin Pharmacol 73(4): 504-17.(2012).

[45] Yang F, Lim GP, Begum AN, Ubeda OJ, Simmons MR, Ambegaokar SS, et al. Curcumin inhibits formation of amyloid beta oligomers and fibrils, binds plaques, and reduces amyloid in vivo. J Biol Chem 280(7): 5892-901.(2005). [46] Kim HY, Kim HV, Lee DK, Yang SH, Kim Y. Rapid and sustained cognitive recovery in APP/PS1 transgenic mice by co-administration of EPPS and donepezil. Sci Rep 6: 34165.(2016).

[47] Weinstein JD. A new direction for Alzheimer's research. Neural Regen Res 13(2): 190-93.(2018).

[48] Schmitt B, Bernhardt T, Moeller HJ, Heuser I, Frolich L. Combination therapy in Alzheimer's disease: a review of current evidence. CNS Drugs 18(13): 827-44.(2004).

[49] Greig SL. Memantine ER/Donepezil: A Review in Alzheimer's Disease. CNS Drugs2015).

[50] Scherbaum WA, Goke B, German Pioglitazone Study G. Metabolic efficacy and safety of once-daily pioglitazone monotherapy in patients with type 2 diabetes: a double-blind, placebo-controlled study. Horm Metab Res 34(10): 58995.(2002). 
bioRxiv preprint doi: https://doi org/10.1101/2020.06 24 168518; this version posted June 24, 2020. The copyright holder for this preprint (which was not certified by peer review) is the author/funder, who has granted bioRxiv a license to display the preprint in perpetuity. It is made available under aCC-BY-ND 4.0 International license.

[51] Galimberti D, Scarpini E. Pioglitazone for the treatment of Alzheimer's disease. Expert Opin Investig Drugs 26(1): 97-101.(2017).

[52] Paz-Filho G, Mastronardi CA, Licinio J. Leptin treatment: facts and expectations. Metabolism 64(1): 14656.(2015).

[53] Gray E, Ginty M, Kemp K, Scolding N, Wilkins A. The PPAR-gamma agonist pioglitazone protects cortical neurons from inflammatory mediators via improvement in peroxisomal function. J Neuroinflammation 9: 63.(2012).

[54] Fernandez-Martos CM, Gonzalez P, Rodriguez FJ. Acute leptin treatment enhances functional recovery after spinal cord injury. PLoS One 7(4): e35594.(2012).

[55] Wojtowicz AK, Szychowski KA, Kajta M. PPAR-gamma agonist GW1929 but not antagonist GW9662 reduces TBBPA-induced neurotoxicity in primary neocortical cells. Neurotox Res 25(3): 311-22.(2014).

[56] d'Abramo C, Massone S, Zingg JM, Pizzuti A, Marambaud P, Dalla Piccola B, et al. Role of peroxisome proliferator-activated receptor gamma in amyloid precursor protein processing and amyloid beta-mediated cell death. Biochem J 391(Pt 3): 693-8.(2005).

[57] Marwarha G, Raza S, Meiers C, Ghribi O. Leptin attenuates BACE1 expression and amyloid-beta genesis via the activation of SIRT1 signaling pathway. Biochim Biophys Acta 1842(9): 1587-95.(2014).

[58] Govindarajulu M, Pinky PD, Bloemer J, Ghanei N, Suppiramaniam V, Amin R. Signaling Mechanisms of Selective PPARgamma Modulators in Alzheimer's Disease. PPAR Res 2018: 2010675.(2018).

[59] Kariharan T, Nanayakkara G, Parameshwaran K, Bagasrawala I, Ahuja M, Abdel-Rahman E, et al. Central activation of PPAR-gamma ameliorates diabetes induced cognitive dysfunction and improves BDNF expression. Neurobiol Aging 36(3): 1451-61.(2015). 
bioRxiv preprint doi: https://doi org/10.1101/2020.06 24.168518; this version posted June 24,2020 . The copyright holder for this preprint (which was not certified by peer review) is the author/funder, who has granted bioRxiv a license to display the preprint in perpetuity. It is made available under aCC-BY-ND 4.0 International license.

\section{FIGURE LEGENDS AND TABLES}

\section{Fig. 1. The schedule of experiment design.}

Male mice about 28 weeks underwent 2 weeks of drug administration. Ten weeks after the drug administration, the brain hemispheres were harvested for the analysis of $\mathrm{A} \beta$ plaque load and Western Blots.

\section{Fig. 2. The analysis of thioflavin-S positive plaque load analysis.}

(a) Plaque load analysis showed the percentages of area stained by thioflavin-S were significantly (*** $<<0.01)$ lower in the HP of APP/PS1 L $+\mathrm{P}$ mice than in APP/PS1 VH mice. And there was no significant decrease of fibrillar A $\beta$ plaques in HP of APP/PS1 APP/PS1 L or APP/PS1 P mice compared to APP/PS1 VH mice. (b) L alone or P alone or $\mathrm{L}$ and $\mathrm{P}$ therapy did not result in differences in fibrillar A $\beta$ load in CTX of APP/PS1 mice relative to VH mice. Bar graphs represent the mean \pm SEM. Statistical analyses were performed by two-way ANOVA followed by Dunnett test. Abbreviations: ANOVA, analysis of variance; CTX, neocortex; HP, hippocampus; L, leptin; P, pioglitazone; SEM, standard error of the mean; Tg, Transgenic (refer to APP/PS1 mice); VH, vehicle.

\section{Fig. 3. MOAß-2-labelled A $\beta$ load in the HP.}

There were no significant alterations to MOA $\beta$-2-labelled A $\beta$ load in either HP (a) or CTX (b) of APP/PS1 L, APP/PS1 P, APP/PS1 L +P mice relative to APP/PS1 mice. Bar graphs represent the mean \pm SEM. Statistical analyses were performed by two-way ANOVA followed by Dunnett test. Abbreviations: ANOVA, analysis of variance; CTX, neocortex; HP, hippocampus; L, leptin; P, pioglitazone; SEM, standard error of the mean; Tg, Transgenic (refer to APP/PS1 mice); VH, vehicle.

\section{Fig. 4. ELISA analysis of $A \beta_{1-42}$ in the HP.}

The amounts of $A \beta_{1-42}$ were significantly $(* \mathrm{p}<0.05, * * \mathrm{p}<0.01)$ decreased in the HP of APP/PS1 mice administered with $\mathrm{L}$ alone or $\mathrm{L}+\mathrm{P}$, compared with APP/PS1 VH mice. Bar graphs represent the mean \pm SEM. Statistical analyses were performed by one-way ANOVA followed by Dunnett test. Abbreviations: ANOVA, analysis of variance, HP, hippocampus; L, leptin; P, pioglitazone; SEM, standard error of the mean; Tg, Transgenic (refer to APP/PS1 mice), $\mathrm{VH}$, vehicle.

\section{Fig. 5. Immunoblotting analysis of the expression of PPAR $\gamma$ protein.}

(a) Representative GAPDH-normalized immunoblotting images. (b) Quantitation of PPAR $\gamma$ in HP extracts from in the HP of WT and APP/PS1 mice administered with $\mathrm{L}$ alone, $\mathrm{P}$ alone or $\mathrm{L}+\mathrm{P}$, and APP/PS1 VH mice at 40 weeks. The combination of $\mathrm{L}$ and $\mathrm{P}$ increased the expression of PPAR $\gamma$ protein in APP/PS1 mice, compared with the single treatment of L or P. Data are expressed as a \% of the WT VH group. Bar graphs represent the mean \pm SEM. Statistical analyses were performed using two-way ANOVA followed by Dunnett test $(* \mathrm{p}<0.05, * * \mathrm{p}<0.01, * * * \mathrm{p}<0.001$ versus 
bioRxiv preprint doi: https://doi org/10.1101/2020.06.24 168518; this version posted June $24,2020$. The copyright holder for this preprint (which was not certified by peer review) is the author/funder, who has granted bioRxiv a license to display the preprint in perpetuity. It is made available under aCC-BY-ND 4.0 International license.

WT VH group; ${ }^{\#} \mathrm{p}<0.05,{ }^{\#} \mathrm{p}<0.01,{ }^{\# \#} \mathrm{p}<0.001$ versus APP/PS1 VH group), while the nonparametric Student $t$ test was used for the comparisons between APP/PS1 L and APP/PS1 L+P groups, and between APP/PS1 P and APP/PS1 $\mathrm{L}+\mathrm{P}$ groups $\left({ }^{\$} \mathrm{p}<0.05,{ }^{\$ \$} \mathrm{p}<0.01,{ }^{\$ \$} \mathrm{p}<0.001, t\right.$ test $)$. Abbreviations: ANOVA, analysis of variance; HP, hippocampus; L, leptin; Tg, Transgenic (refer to APP/PS1 mice); P, pioglitazone; SEM, standard error of the mean; VH, vehicle; WT, wild type.

Table 1. Different treatments on WT and Tg mice.

\begin{tabular}{l|l}
\hline \multicolumn{1}{c|}{ Tg: APP/PS1 mice } & \multicolumn{1}{c}{ WT: wild type mice } \\
\hline Group 1: IN Leptin + IP Piolitazone (L+P) & Group 5: IN Leptin + IP Piolitazone (L+P) \\
\hline Group 2: IN Leptin + IP Vehicle (L) & Group 6: IN Leptin + IP Vehicle (L) \\
\hline Group 3: IN Vehicle + IP Piolitazone (P) & Group 7: IN Vehicle + IP Piolitazone (P) \\
\hline Group 4: IN Vehicle + IP Vehicle (VH) & Group 8: INVehicle + IP Vehicle (VH) \\
\hline
\end{tabular}

Abbreviations: IN, Intranasal; IP, intraperitoneal; Tg, Transgenic; VH, vehicle; WT, wild type.

Table 2. Numbers of mice used in each analysis.

\begin{tabular}{l|l|l|l|l|l|l|l|l}
\hline & Tg VH & Tg L & Tg P & Tg L+P & WT VH & WT L & WT P & WT L+P \\
\hline ThioS & 6 & 9 & 7 & 5 & - & - & - & - \\
\hline MOA $\beta$ & 5 & 9 & 6 & 3 & - & - & - & - \\
\hline ELISA & 3 & 5 & 5 & 3 & - & - & - & - \\
\hline WB & 3 & 5 & 5 & 3 & 5 & 5 & 5 & 5 \\
\hline
\end{tabular}

Abbreviations: WT, wild type; Tg, Transgenic (refer to APP/PS1 mice); ThioS, thioflavin-S; ELISA, enzyme-linked immunosorbent assay; WB, Western blotting. 
Drug

Administration

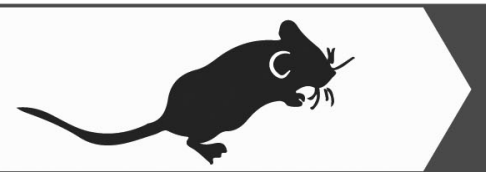

Age (weeks) 28
Tissue

Harvest

A pladu study

${ }^{8}{ }_{O}$

40

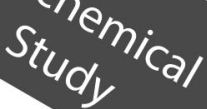



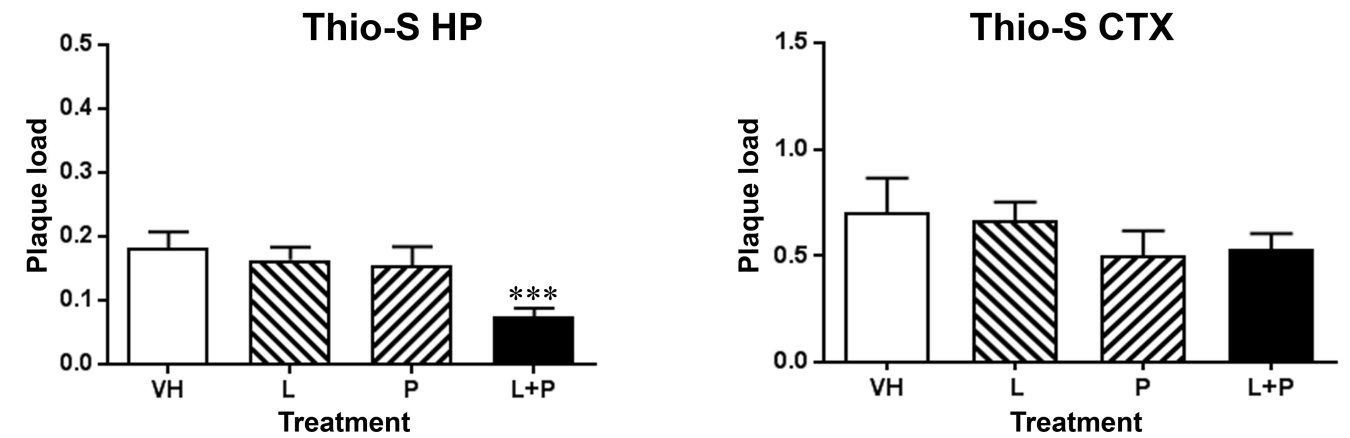
A

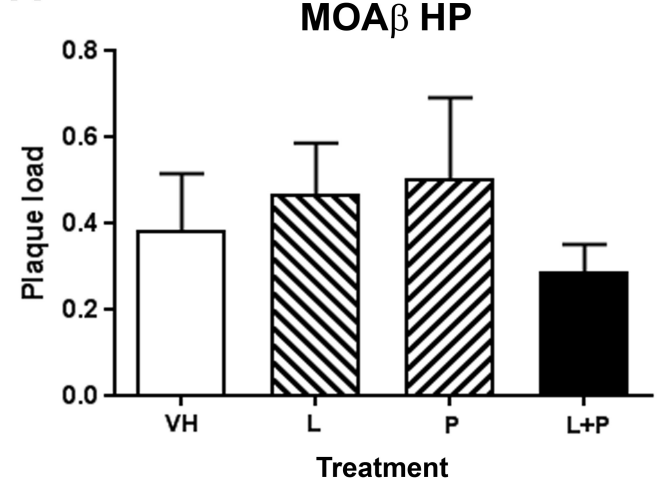

B

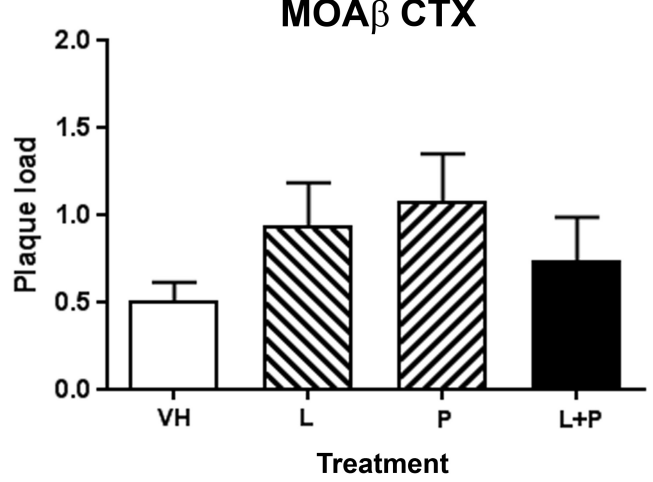




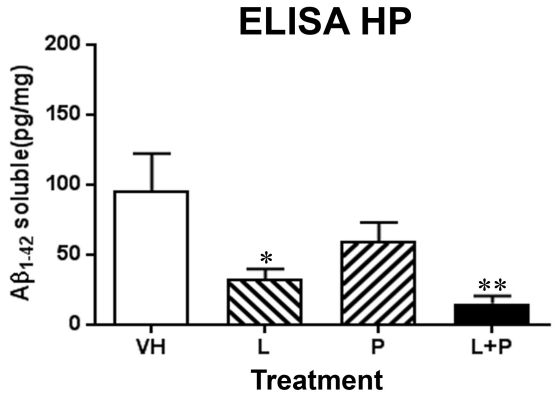


A
WT
TG
VH L
P L+P
VH L
P L+P

PPAR $\gamma$

GAPDH

B

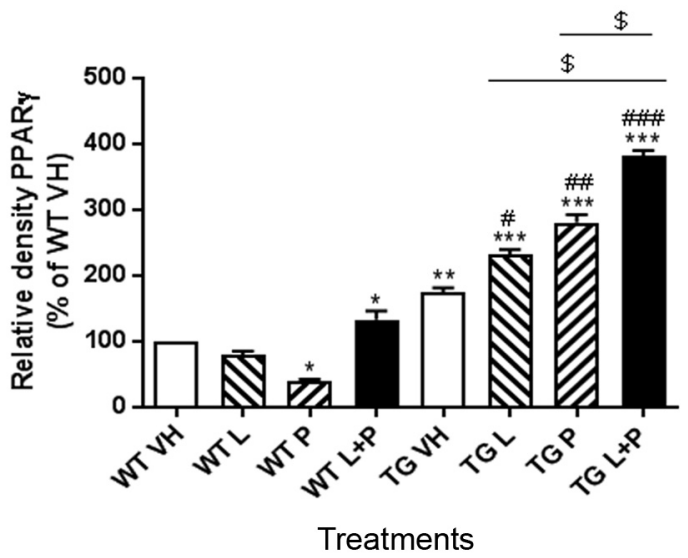

